\title{
Growth and Photosynthetic Pigments Accumulation of Jute Mallow (Corchorus olitorius Linn) in Response to Different Levels of Magnesium Application
}

\author{
Ezekiel Dare OLOWOLAJU ${ }^{1 *}$, Olarewaju Gideon OKUNLOLA², \\ Alimat Ololade AYODELE ${ }^{1}$
}

\author{
${ }^{1}$ Obafemi Awolowo University, Faculty of Science, Department of Botany, Ile-Ife, Nigeria; ezekieldare12@yahoo.com (*corresponding author) \\ ${ }^{2}$ Osun State University, Faculty of Science, Department of Biological Sciences, Osogbo, Nigeria;
}

\begin{abstract}
The hereby study investigated the effect of Magnesium application at different levels on the morphological parameters and photosynthetic pigment accumulation of Corchorus olitorius. Seeds of C. olitorius were utilized in the experiment. These seeds were sown in 2 big bowls and were supplied with $200 \mathrm{ml}$ of water every day until they were fully established. After three weeks of sowing, the seedlings were transplanted into plastic pots. The treatments were: distilled water (control); nutrient solution in which the concentration of Magnesium was increased by the factor of 5 (N5), nutrient solution in which the concentration of Magnesium was increased by the factor of 10 (N10) and nutrient solution lacking Magnesium source (NMg). The seedlings were then divided into 4 regimes, with each regime containing each treatment. From the results obtained, it was observed that there was a significant effect at $(\mathrm{P} \geq 0.05)$ on the Corchorus olitorius growth parameters and photosynthetic pigment accumulation among the treatments. There was an increase in the shoot height, number of leaves, number of flowers, leaf area and the photosynthetic pigment accumulation in the seedlings treated with magnesium increased by the factor of 5 (N5) than by other treatments. The control recorded the lowest values for these parameters. It can be concluded that for an optimum growth of Corchorus olitorius, it can be inferred that the plant can do well in nutrient solution having Magnesium source (at moderate level).
\end{abstract}

Keywords: accumulation, growth, magnesium, nutrient, pigment

\section{Introduction}

Deficiencies in plant nutrients, particularly the macronutrients, can adversely affect plant growth and yield (Fageria and Baligar, 2005). Depending on the specific nutrient, a lack of these elements can cause stunted growth, slow growth, or chlorosis. Extreme deficiencies may result in leaves showing signs of cell death. Visual symptoms, soil and plant analysis are the common practices for identifying nutritional disorder in crop plant (Fageria and Baligar, 2005). The best criterion, however, for diagnosing nutritional deficiency in annual crops is through evaluating crop responses to applied nutrient. If a given crop responds to an applied nutrient in a given soil, this means that the nutrient is deficient for that crop. Relative decrease in growth and yield in the absence of a nutrient as compared to an adequate soil fertility level can give idea of the magnitude of nutrient deficiency (Fageria and Baligar, 2005).

Magnesium (Mg) is one of the important macronutrients. It is important to the photosynthetic process. Magnesium occurs typically as the $\mathrm{Mg} 2+$ ion. It is an essential mineral nutrient (element) for life and is present in every cell type in every organism. Without sufficient amounts of magnesium, plants begin to degrade the chlorophyll in the old leaves. This causes the main symptom of magnesium deficiency, chlorosis, or yellowing between leaf veins, which stay green, giving the leaves a marbled appearance. Due to magnesium's mobile nature, the plant will first break down chlorophyll in older leaves and transport the $\mathrm{Mg}$ to younger leaves, which have greater photosynthetic needs. Therefore, the first sign of magnesium deficiency is the chlorosis of old leaves which progresses to the young leaves as the deficiency continues (Hermans et al., 2006). Magnesium also is a necessary activator for many critical enzymes, including ribulosbiphosphate carboxylase ( $\mathrm{RuBis} \mathrm{CO})$ and phosphoenolpyruvate carboxylase (PEPC), both essential enzymes in carbon fixation. Thus, low amounts of $\mathrm{Mg}$ lead to a decrease in photosynthetic and enzymatic activity within the plants. Magnesium is also crucial in stabilizing ribosome structures, hence, a lack of magnesium causes depolymerization of ribosomes leading to pre-mature aging of the plant. After prolonged magnesium deficiency, necrosis and dropping of older leaves occurs. Plants deficient in magnesium also produce smaller, woodier fruits (Norman et al., 2000). 
Corchorus olitorius belongs to the family of Malvaceae. C. olitorius is mainly known for its fibre product, jute and for its leafy vegetables (Schippers et al., 2002). The leaves are a rich source of iron, protein, calcium, thiamin, riboflavin, folate, and dietary fibre (Palada and Chang, 2003). Root scraping of $C$. olitorous is used for the treatment of toothache and root decoction as tonic (Schippers, 2000). The leaves are used for the treatment of gonorrhea and as purgative and febrifuge (Burkill, 2000). Jute leaves are extremely consumed in many parts of the world including Japan, China, India and many places within the Africa including Nigeria because it contains abundant carotenoids, vitamin B1, B2, C and E, minerals. The darkgreen leaves of $C$. olitorius have varying proportion of $\mathrm{Ca}$, $\mathrm{Fe}, \beta$-carotene, vitamin $\mathrm{C}$, fiber and protein required for health (Schippers, 2000).

Leafy vegetable such as $C$. olitorius require specific amounts of both micronutrients and macronutrients for good vegetative growth and yield. The quality of the harvest and storability are influenced by the availability of essential minerals in balanced proportion. Any deviation from the balanced proportion of nutrients is easily noticed on the growth and yield of $C$. olitorius as deficiency symptoms (Aluko et al., 2014).

Hence, there is need to study the effects of nutrient application on the morphological parameters and the photosynthetic pigments accumulation of $C$. olitorius. The specific objective of this study was to investigate the effect of different levels of magnesium application on the morphological parameters and photosynthetic pigments of C. olitorius.

\section{Materials and Methods}

The seeds of a single variety of Corchorus olitorius were use in the experiment. The seeds were collected from the National Institute of Horticulture (NIHORT), Ibadan, Oyo state, Nigeria. Two big bowls and 32 plastic pots (of about $22 \mathrm{~cm}$ in height and $25 \mathrm{~cm}$ in diameter) were made use of. Holes of equal diameter were bored at the bottom of the bowls and pots to allow proper drainage and prevent water logging during the course of the experiment. These bowls were filled near brim with collected soil.

Seeds of $C$. olitorius were sown into the big bowls serving as the nursery. After 3 weeks of sowing and the seedlings were fully established, the germinated seedlings were transplanted into the 32 plastic pots with two seedlings per pot. The 32 plastic pots were divided into 4 groups, each group containing 8 plastic pots. Each group served as a regime. The first regime was the control, which was supplied with water every day. The second regime was supplied with complete nutrient solution. The third regime was treated with magnesium increased by the factor of 10 . And the fourth regime was treated with nutrient solution lacking magnesium. The nutrient solutions were supplied to the seedlings once every day and well-watered. The magnesium source used during the experimental project was $\mathrm{MgSO} 4.7 \mathrm{H} 2 \mathrm{O}$. An experiment laid out in a randomized complete block design (RCBD) with four replicates was used. The treatments were Control = water every day, $\mathrm{NMg}$ $=$ no Magnesium, $\mathrm{N} 5=$ with magnesium increased by the factor of 5 , and $\mathrm{N} 10=$ with magnesium increased by the factor of 10 . The nutrient solution was prepared in accordance with the modified long Ashton formula (Hewitt, 1952) as shown in Table 1.

Sampling was carried out after three weeks of sowing when the seedlings were fully established. This was further done at 5-days interval. Measurements of morphological parameters were taken. These parameters included shoot height, leaf length and leaf width, measured with the aid of a metric rule calibrated in $1 \mathrm{~cm}$, and number of leaves, which were counted manually. Leaf area (LA), leaf area ratio (LAR) and root to shoot ratio (RSR) where determined as follows:

\section{$\mathrm{LA}=\mathrm{L} \times \mathrm{W} \times 0.75$}

$\mathrm{L}$ and $\mathrm{W}$ are the leafs length and width respectively and 0.75 is the correction factor of the leaf (Vile et al., 2005).

$\mathrm{LAR}=\mathrm{LA} / \mathrm{Ws}$

Ws represent the dry weight pf plant (Vile et al., 2005).

$\mathrm{RSR}=\mathrm{W} 3 / \mathrm{W} 2$

W3 and W2 are the root weight and shoot weight respectively (Mulanax, 2005).

\section{Determination of chlorophyll}

From each plant, $8 \mathrm{~g}$ of leaves were harvested, from each pot (the control, NMg, N5 and N10); the leaves were ground with mortar and pestle. A pinch of sodium bicarbonate was added to the mixture to prevent the degradation of chlorophyll. $16 \mathrm{ml}$ of $80 \%$ acetone were added. The blended materials were then filtered through a Whatman's No. 1 filter paper. The absorbance of the samples was determined on a digital spectrophotometer at wavelengths of $470 \mathrm{~nm}, 646 \mathrm{~nm}$ and $663 \mathrm{~nm}$. Beer-Lambert equations were used to determine the concentrations of Chlorophyll $a$ and Chlorophyll $b$ and the carotenoid as follows:

Chlorophyll $a(\mu \mathrm{g} / \mathrm{ml})=12.21 \mathrm{~A} 663-2.81 \mathrm{~A} 6$

Chlorophyll $b(\mu \mathrm{g} / \mathrm{ml})=20.13 \mathrm{~A} 646-5.03 \mathrm{~A} 66$

Carotenoids $(\mu \mathrm{g} / \mathrm{ml})=(1000 \mathrm{~A} 470-3.27[\mathrm{Chl} a]-$ $104[\mathrm{Chl} b]) / 227$

Total chlorophyll $(\mu \mathrm{M})=7.93$ A663 +19.53 A646

Table 1. The composition of nutrient solution

\begin{tabular}{|c|c|}
\hline Nutrient solution & Amount $\left(\mathrm{gl}^{-1}\right)$ \\
\hline \multicolumn{2}{|l|}{ Macronutrients } \\
\hline $\mathrm{KNO}_{3}$ & 0.216 \\
\hline $\mathrm{NH}_{4} \mathrm{NO}_{3}$ & 0.029 \\
\hline $\mathrm{CaCl}_{2}$ & 0.553 \\
\hline $\mathrm{K}_{2} \mathrm{SO}_{4}$ & 0.348 \\
\hline $\mathrm{NaH}_{2} \mathrm{PO}_{4} \cdot 2 \mathrm{H}_{2} \mathrm{O}$ & 0.2104 \\
\hline $\mathrm{MgSO}_{4} \cdot 7 \mathrm{H}_{2} \mathrm{O}$ & 0.3801 \\
\hline Ferric citrate & 0.053 \\
\hline \multicolumn{2}{|l|}{ Micronutrients } \\
\hline $\mathrm{MnSO}_{4}$ & 0.003 \\
\hline $\mathrm{CuSO}_{4}$ & $3.537 \times 10^{-4}$ \\
\hline $\mathrm{ZnSO}_{4 .} .7 \mathrm{H}_{2} \mathrm{O}$ & $3.079 \times 10^{10-4}$ \\
\hline $\mathrm{H}_{3} \mathrm{BO}_{3}$ & 0.0019 \\
\hline$\left(\mathrm{NH}_{4}\right)_{6} \mathrm{MO}_{7} \mathrm{O}_{2} \cdot 4 \mathrm{H}_{2} \mathrm{O}$ & $0.368 \times 10^{10-4}$ \\
\hline $\mathrm{CoSO}_{4 .} 7 \mathrm{H}_{2} \mathrm{O}$ & $0.286 \times 10^{10-4}$ \\
\hline $\mathrm{NaCl}$ & 0.0058 \\
\hline
\end{tabular}


216

This was done at the vegetative stage, flowering stage and the fruiting stage.

Statistical analysis was performed using statistical analytical software, SAS version 9.2. One-way analysis of variance (ANOVA) was carried out to investigate the effect of magnesium stresses on the morphological parameters. Post hoc testing was carried out using Fisher's LSD to separate the means at $\mathrm{p} \leq 0.05$.

\section{Results and Discussion}

There was a gradual increment from the beginning of the experiment to the end of the experiment in the seedlings of $C$. olitorius grown under different magnesium treatments as shown in Fig. 1. The plants with concentration of magnesium increased by the factor of 5 (N5) recorded the highest increments of all the treatments. Towards the end of the experimental period, the shoot height of N5 was significantly different from that of N10, NMg and control but there was no significant difference between the shoot height of N10, NMg and control at $\mathrm{P} \geq 0.05$.

There was an increase in the number of leaves from the beginning of the experiment towards the end of the experiment in the seedlings of $C$. olitorius grown under different magnesium treatments as shown in Fig. 2. The N5 plants have the highest number of leaves, while the control has the least number of leaves. Towards the end of the experimental period, the result shows that the leaf number of $\mathrm{N} 5$ was significantly different from that of $\mathrm{N} 10, \mathrm{NMg}$ and control, but there was no significant difference between N10, NMg and control P $\geq 0.05$.

The observed higher shoot height and number of leaves in N5 plants was due to subsequent build-up of assimilates in plants, which was in agreement with the findings of Putra et al. (2012), who found out that the application of magnesium had positive influence on the uptake of other nutrients by wheat straw thereby increasing its shoot height. Also, magnesium application enhances the stomatal width, length and transpiration rate in wheat straw (Putra et al., 2012).

The leaf areas of $C$. olitorius plants in the different levels of magnesium application are shown in Fig. 3. There was a gradual increase in all the treatments from the first week to the fourth week, but a fluctuation occurred from the 4th to the 5th week, after which the leaf area increased further till the end of the experiment. The plants treated with the concentration of magnesium increased by the factor of 5 recorded the highest leaf area, while the control recorded the least leaf area measurement. The control plants showed a significant difference at $\mathrm{P} \geq 0.05$ from the other treatments for the 3rd week, but there was significant difference among the N5, N10, and NMg and control plants towards the end of the experiment.

The leaf area ratio of $C$. olitorius plants in the different levels of magnesium application is shown in Fig. 4. There was a gradual increase from the 3 rd week towards the end of the experiment. In the 3rd week, the N10 plants had the highest leaf ratio, while the NMg plants had the highest leaf ratio in the 4th week. From the 5 th week to the end of the experiment, the control plants had the highest leaf ratio. In the early weeks of the experiment, there was no significant difference at $\mathrm{P} \geq 0.05$ among the plants under the different

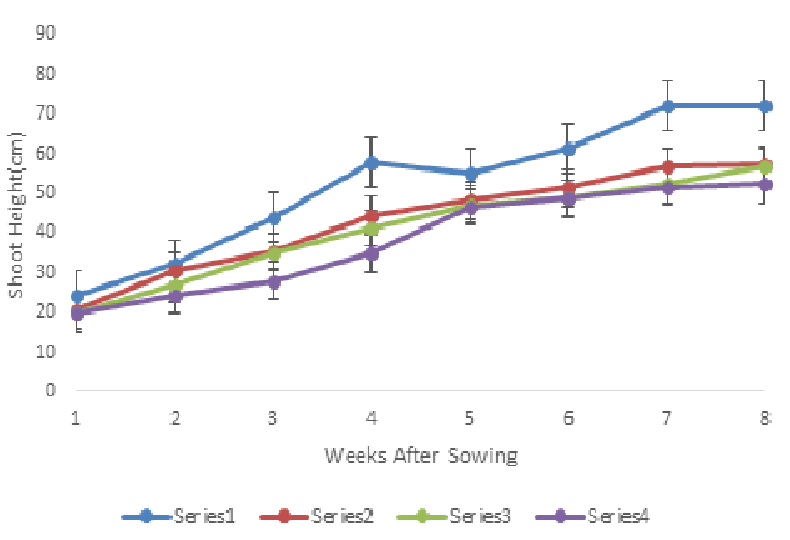

Fig. 1. The effect of Magnesium application on the shoot height of $C$. olitorius grown under different levels of nutrient solution

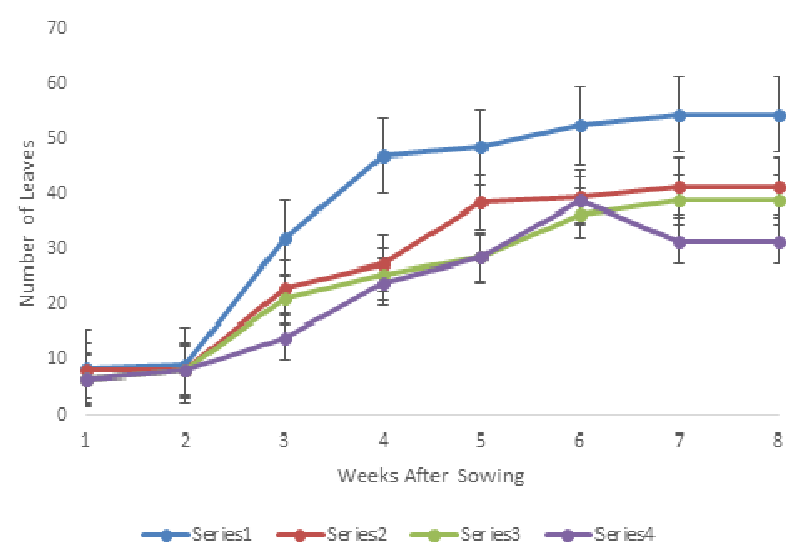

Fig. 2. The effect of Magnesium application on the number of leaves of $C$. olitorius grown under different levels of nutrient solution

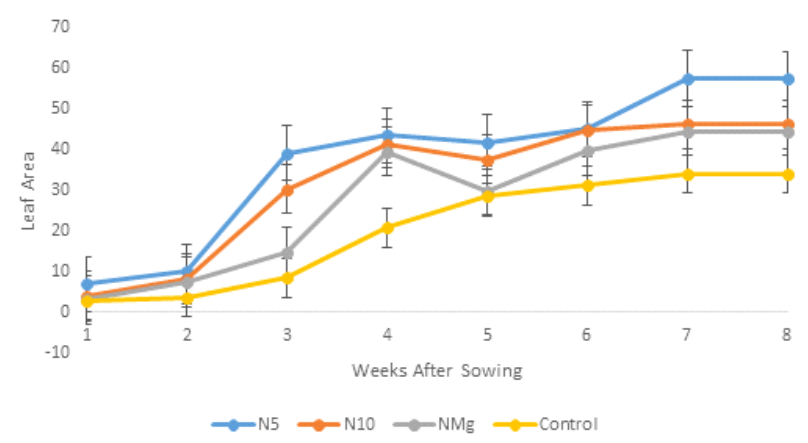

Fig. 3. The effect of different levels of Magnesium application on the leaf area of $C$. olitorius

magnesium treatment but towards the end of the experimental period, the control plants showed a significant difference from the N5 plants, N10 plants and the NMg plants. The highest leaf area recorded in N5 plants and lowest leaf area recorded in $\mathrm{NMg}$ and $\mathrm{N} 10$ was also reported by Huber and Jones (2013), noting that magnesium is an essential element for plants and as a component of the abiotic environment and suitable for photosynthesis resulting in large leaf area. Lack of 
Table 2. The effect of Magnesium application at vegetative stage of the photosynthetic pigment accumulation of $C$. olitorius

\begin{tabular}{|c|c|c|c|c|}
\hline \multirow[t]{2}{*}{ Stages } & \multirow[t]{2}{*}{ Treatments } & \multicolumn{3}{|c|}{ Days after Sowing } \\
\hline & & Carotenoids & Chlorophyll $a$ & Chlorophyll $b$ \\
\hline \multirow[t]{5}{*}{ Vegetative } & N5 & $4.67^{\mathrm{a}}$ & $3.04^{\mathrm{a}}$ & $1.31^{\mathrm{a}}$ \\
\hline & N10 & $3.32^{\mathrm{b}}$ & $1.44^{\mathrm{b}}$ & $0.46^{\mathrm{b}}$ \\
\hline & Control & $2.88^{\mathrm{c}}$ & $1.38^{\mathrm{c}}$ & $0.38^{\mathrm{c}}$ \\
\hline & $\mathrm{NMg}$ & $2.26^{\mathrm{d}}$ & $1.11^{\mathrm{d}}$ & $0.3^{\mathrm{d}}$ \\
\hline & LSD & 0 & 0 & 0 \\
\hline \multirow[t]{5}{*}{ Flowering } & N5 & $9.61^{a}$ & $-9.41^{a}$ & $-15.10^{\mathrm{a}}$ \\
\hline & N10 & $8.83^{\mathrm{b}}$ & $-9.41^{a}$ & $15.10^{\mathrm{a}}$ \\
\hline & Control & $8.82^{\mathrm{c}}$ & $-9.41^{a}$ & $15.10^{\mathrm{a}}$ \\
\hline & $\mathrm{NMg}$ & $8.6^{\mathrm{d}}$ & $-9.41^{a}$ & $15.10^{\mathrm{a}}$ \\
\hline & LSD & 0 & 0 & 0 \\
\hline \multirow[t]{5}{*}{ Fruiting } & N5 & $9.13^{\mathrm{a}}$ & $-9.41^{a}$ & $15.10^{\mathrm{a}}$ \\
\hline & N10 & $8.75^{\mathrm{b}}$ & $-9.41^{a}$ & $15.10^{a}$ \\
\hline & Control & $8.74^{\mathrm{c}}$ & $-9.41^{\mathrm{a}}$ & $15.10^{\mathrm{a}}$ \\
\hline & $\mathrm{NMg}$ & $7.97^{\mathrm{d}}$ & $-9.41^{a}$ & $15.10^{\mathrm{a}}$ \\
\hline & LSD & 0 & 0 & 0 \\
\hline
\end{tabular}

Means with the same superscripts within the same column does not have significant difference $(\mathrm{P}>0.05)$

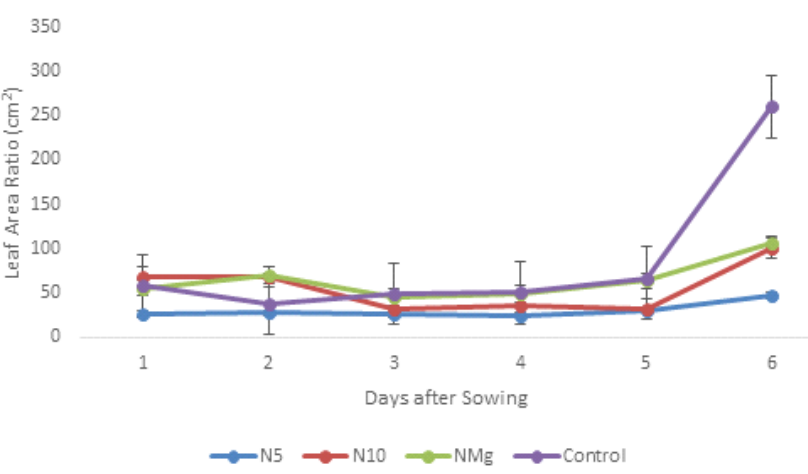

Fig. 4. The effect of different levels of Magnesium application on the leaf area ratio of $C$. olitorius

magnesium lead to a reduction in leaf area (Huber and Jones, 2013).

The result of photosynthetic pigment accumulation at different stages of growth in different levels of nutrient treatment is shown in Table 2. It can be inferred that N5 plants had a significant higher chlorophyll $a$, chlorophyll $b$ and carotenoid accumulation at the vegetative, flowering and fruiting stage, while the NMg plants had significant lesser chlorophyll $a$, chlorophyll $b$ and carotenoid accumulation at the vegetative, flowering and fruiting stage. Also, it can be inferred that magnesium concentration at different level has no significant difference $\mathrm{P} \geq 0.05$ on chlorophyll $\mathrm{a}$ and $\mathrm{b}$ at both the flowering and fruiting stage, but has a significant effect on the chlorophyll $a$ chlorophyll $b$ and carotenoid accumulation at the vegetative stage.

The significant higher photosynthetic pigment accumulation observed in N5 plants is in accordance with the findings of Wilkinson $e t$ al. (1990) who observed that magnesium plays a critical role in capturing solar energy and releasing it to the photochemical process of photosynthesis, given that up to one fifth of the magnesium structural pool is involved in the chlorophyll structure. Therefore, the higher photosynthetic pigment accumulation in N5 plants may be as a direct result of the moderate concentration of magnesium, while the lower photosynthetic pigment accumulation observed in and NMg is because magnesium is lacking, which reduces the rate at which chlorophyll absorbs light.

\section{Conclusions}

The growth and photosynthetic pigments accumulation of C. olitorius were enhanced in nutrient solution having magnesium source at moderate level more than the other treatments (N10, NMg and control).

\section{Acknowledgements}

Sincere and profound gratitude goes to Prof. A.A. Adelusi, for his invaluable guidance and fatherly advice throughout the duration of this research work.

\section{References}

Aluko OA, Olanipekun TO, Olasoji JO, Abiola IO, Adeniyan ON, OlanipekunSO, Omenna EC, Kareem KO, Douglas AI (2014). Effect of organic and inorganic fertilizer on the yield and nutrient composition of Jute Mallow. Global Journal of Agriculture Research 2(3):1-7.

Burkill HM (2000). The useful plants of West Tropical Africa. 2nd ed families S-Z,Royal Botanical gardens, Kew, United Kingdom.

Combs JH, Long SI, Scurlock J (1985).Technique in bioproductivity and photosynthesis. Pratley Journal pp 223-225.

Fageria NK, Baligar VC (2005). Nutrient availability. In: Hillel D (Ed). Encyclopedia of Soils in the Environment pp 63-71.

Hermans C, Vuylsteke F, Coppens F (2005). Systems analysis of the responses to long-term magnesium deficiency and restoration in Arabidopsisthaliana. New Phytologist 187:132-144.

HewittEJ (1952). Sand and water culture methods used in the study of plant nutrition. Commonwealth Bureau of Horticulture and Plantation Crops Technical Communication pp 22.

Huber DM, Jones JB (2013). The role of magnesium in plant disease. Plant and Soil 368(1-2):73-85.

Norman PA, William H, Merhaut DJ, Hermans C (2000). Introduction to Plant Physiology, 4thed.John Wiley \& Sons, Inc.

Putra ET, Zakaria W, Abdullah NA, Saleh GB (2012). Stomatal morphology, conductance and transpiration of Musa sp. cv. Rastali in relation to magnesium, boron and silicon availability. America Journal of Plant Physiology 7:8496. 
218

Schippers RR (2000). African indigenous vegetables. An overview of the cultivated species. Natural Resources Institute/ ACP-EU Technical Center for Agricultural and Rural Cooperation, Chatam, United Kingdom pp214.

Vile D, Garnier E, Shipley B, Laurent G, Navas ML, Roumet C (2005). Specific leaf area and dry matter content estimate thickness in laminar leaves. Annals of Botany 96:1129-1136.
Wilkinson SR, Welch RM, Mayland MF, Grunes DL (1990). Magnesium in plants; uptake, distribution, function, and utilization by man and animals. In: Sigel H, Sigel A (Eds). Metal ions in biological systems: compendium on magnesium and its role in biology, nutrition, and physiology. Marcel Dekker, New York, NY, USA pp 33-56. 